\title{
The seismicity of Iran. \\ The Silakhor (Luristan) earthquake of 23rd Ianuary, 1909 (Part II)
}

\author{
N. N. AMBRASEYs $(*)$ \\ Received on September 13rd, 1974
}

\begin{abstract}
Sumary. - This paper shows that given certain conditions it is perfectly faasible to study an earthquake that occurred three-quarters of a rentury ago in a remote part of the world. Also, it shows that there are many large earthquakes which, because of lack of interdisciplinary efforts to study such events, have remained hitherto little known or totally unknown. The ease of the Silakhor earthyuake revealed defieiencies in the determination of epicentres by ISS and Gutenberg; the difference between macroseismic and instrumental position for the Silakhor earthquake is 380 kilometres, a difference which has caused a serious problem in the assessment of seismicity of Iran. Aceurate macroseismic data mas be used to minimize bias in the instrumental relocation of the larger events and to study source mechanisms. Untill this study was undertaken, the faulting associated with the Silakhor earthquake was totally unknown. Even more important than the value of recent faulting for its significance in resolving ambiguities in the choice of the true somre parametres, is the information that can be grleaned from evidence for the mechanism of earthquakes that occurred long before the advent of modern seismology and in particular, for the pat. tern of recent tectonic activity.
\end{abstract}

Risssuso. - Questa nota dimostra come, date determinate condizioni, sia possibile studiare perfettamente un terremoto avvenuto 75 anmi or sono in una remota parte del mondo, mentre di molti grandi eventi si conosec poco o niente proprio per mancanza di sforzi comuni per st udiarli. La determinazione di epicentri nel terremoto di Silakhor (da parte delless e di Gutenberg) ha rivelato alcune inesattezze: la differenza fra lepicentro

(*) Imperial College of Science \& Technology, London 
macrosismico o quello strumentale è di $380 \mathrm{~km}$, una differenza che laa procurato un problema serio nella distribuzione della sismicita dell' Iran. Dati malcro. sismici accurati permettono di ridure al minimo le differenze nella ricollocazione degli eventi (eon i dati strumentali) o di studiarne il meceanismo focale. Finché questo studio non è stato intrapreso, la faglia associata al terremoto di Nilakhor s stata totalmente sconosciuta. Più che per il contributo dato nel risolvere ambigaitid nella seelta dei parametri relativi alla vera sorgente, lat recente faglia è importante pes le informazioni che essa fornisce nello studio del meccanismo di terremoti che sono avvenuti molto tempo prima dellavvento della moderna sismologia e, in particolare, por il modello della recente attivita tetonica.

\section{INTRODUCTION}

During the writing of the paper on the Silakhor earthquake of 1909 (41), an important umpublished document came to our attention (58), unfortunately too late to be fully incorporated into the paper.

This find, apart from its significance for the information it contains, raised the question of how much additional information about this particular event, or for that matter about other historical earthquakes is likely to have survived in various offices of public records and archives and of how such information could be retrieved. While writing the Silakhor paper, the most rearlily accessible state documents of the period were searched (*), but these were found to contain little more than summaries of consular reports from Persia dealing chiefly with political events and trade statistics.

Taking the Silakhor earthquake of 1909, therefore, as a test-case of an event that happened 65 years ago in a remote part of Persia, we attempted a search in various archives in this country as well as in Iran and in other countries which at the time of the earthquake maintained consulates and trade missions in Persia. We looked for published and umpublished information that could throw more light on the effects of this important event. Much of the present paper, therefore, is derived from new evidence which was found during this search as well as from arditional work carried out in the Silalkhor area that completes our knowledge about this event. In a sense this paper is a continuation of that publisherl earlier (**), and it is written with the dual object of

(*) Command Papers (1909; 4581/78) (1910; 4962); State Papers (1909; $4559)(1910 ;+365)$.

$(* *)$ Figures and reforences in this paper are numbered in continuation of those in $(41)$. 
answering a number of questions raised earlier about this arthquake in the Zagros momtains $\left({ }^{41}\right)$, and in particular of showing that muler certain comblitions it is perfectly possible to docmment historical anthquakes and to retrieve useful information that may help explain the long-term seismicity and tectomics of areas which nutil recently appeared to be seismically quiescent.

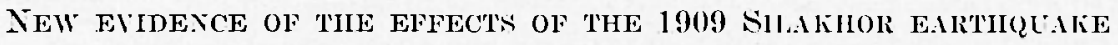

It can now be established that the first news about the Silakhor earthquake reached Kermanshah by post from Burujirl two weeks after the event, on the ath February 1909, and that it was on his own intiative and not at the instigation of Prince (talitzin that the Russian consul in Kermanshal, N. Nikolski, decided to send a fieli party in search of the epicentral area. In his report the consul says:

"In view of the considerable scientific importance of the data, no matter how approximate, that could be obtained about this earthquake which occurred in such a remote comntry devoid of any Europeans, and also because of the rumours of the great levastation that it caused among the loeal people. I, not being able personally to leave my post in Kermanshah, particularly not having a secretary to replace me, hald the day following the receipt of the post from Burujirl, 25th of Jamuary cold style) immediately ordered the newly appointed agent of the consulate Asad Allah Mirza to proceed to Burujirl"' ("51).

The mission, which carried a letter addressed to the Governor of Luristan, Amir Afkhan, arrived in Burujirl on the 10th February, via Bisitun - Sahneh - Kangavar - Fassf - Avar Zaman and Ushuturinan, questioning people along the route. After spending almost five days in Burujird the mission manched to the earthquake region, which it entered on the 15th February. They spent in all ten days only survering the damage in the Silakhor valley before they were ordered back to Kermanshalh, allegedly because of the threat of an epidemic. Nikolski, in his report says that:

"fearing that the Agent and the cossacks sent by me might fall ill in the infected comntryside, I have ordered them to return to Kermanshall; because of this they were able to visit only 
part of the region struck by the earthquake, having gone as far as the village of Bahrain (I)orucl) $\left(^{53}\right)$.

It is questionable, however, with the mission in the field only for ten days, that the news of an impending epirlemic reached Kermanshah so quickly that the consul's recall orders had time to arrive in Silakhor. Nikolski, in his report says nothing of the imminent rising of the Kalkur Kurds around Kermanshah and the activities of the Qaed Rahmat. tribes which, soon after the earthquake, occupier a number of ruiner villages and busierl themselves carrying away the buried stores of grain and home property, activities that might have hastened the return of the mission (*). That the threat of the epirlemic was not wholly responsible for the premature return of the mission to Kermanshah is supported by Nikolski's own statement when, in another report he says:

"To confirm the truth (that the area of clevastation extenderl to the southeast of Bahrain) by sending my Agent beyond the boundaries of the district for which I am responsible, seemerl to be outside my origrinal aim" (51).

The mission was back in Kermanshah on the 1st March, marching back via Burujird - Ushuturinan - Nehavend - Kangavar - Sahneh Bisitun.

News about the earthquake reacherl Tehran three weeks after the event. On February 18th, Sir G. Barcley sent a telegram from Tehran to Capt. Haworth at Kermanshah asking for details of the Luristan earthquake (**). Haworth's consular diary for the week ending 2 February, harl given nothing of importance for Kermanshah. On 21 st February, Haworth sent a telegram from Hamalan to Tehran:

"Slight earthquake shocks Kermanshah and Hamadan early morning January 23 sharper Sultanabad. Stated some villages suftered between Sultanabar and Burujird details very undefinite. Sultanabal should have information".

A further telegram followed from Haworth at Malayer on the th March:

$\left(^{*}\right)$ 1. O/Confilential 1)iary Ahva/Corr. Files no. 70/713 Mareh 1909. (**) F.O. $248 / 968$ 
"Monsieur (undecipherable) late of the Post Office at Resht informs me that 47 villages were destroyed by the arthquake, that he saw a mountain which had been split in two, 35 miles from Burujird causing landslip which buried two villages and leaving gap 500 yards wide. Loss of life computed at 6,000 . Damage commences 18 miles from Burujirl. Shall I go to Burujirl which is 21 miles away from here and get correct details?'?

It does not appear that he was instructed to do so, and the subsequent situation in Kermanshah was sufficiently serious to fully preoceupy the Consul's time. Although this is therefore all that he seems to have done on the matter of the earthquake, such information was clearly of interest to Tehran. In the Kermanshah Consular Diary for the period ending 20th February, the earthquake was mentioned much as described in the cable of 21 st February with the arlitional information that the shock occurred at about 6.0. a.m. On receiving the Diary, Sir G. Barcley wrote thereon; "Summary; you will mention the earthquake of which there were some further particulars from an outsider in a telegram from Haworth" (*).

The news of the Silakhor earthquake reached Bushire and $A$ hwaz some time in the middle of March and they are recorded in the diaries of the British Consuls in these two towns (**). About the same time, a detailed account of the results of the earthquake in the Burujirl district was received by the British Consul in Ahwaz (***), who paraphrased the original Persian Text of this account and included it in his diary. It is unlikely that this detailed account was derived from Nikolski's report, not only because these two documents cover completely different aspects of the earthquake, but also because it was not until a month later, on the 18th April, that the British Consulate in Ahwaz became aware of the Russian activities in the Silakhor valley for which the British Consul shows in his diary evident signs of distrust:

"It is reported" he says "on good authority that about two months ago two Russians dressed as cossacks came to Burujircl. Shortly afterwards a wire was received in Burujird from the

(*) I., 0, $248 / 968$ $72 / 1017$

(**) $1.0 / \mathrm{L} / \mathrm{P} \& \mathrm{~S} / 7 / 227$ no. 11/595; no. 13/647; I.O./I.C.K. 110. 71/850;

(***) I. O/Confidential Diary Ahraz/Corr. Files no. 70;713 Mareh 1909 
Sarle Azam, saying that another Russian accompanied by his interpreter was coming to investigate the clamage done by the anthquake. On arrival of the latter, who is said to be the Russian Gonsul's Deputy from Kermanshah, a house was taken on one year's lease. The interpreter is said to be a man of good birth from Kermanshah. After making exhaustive enquiries as to the roads, stages, etcetera in the district, the latter arrival and his interpoter stanted towarls the Tsfahan road ria Silakhor and Chahar Lang Balkhtiari, with the ostensible object of visiting the places devastated by the earthqualie. They were escorted by a party moler the Mansum al Mamalik, who had been appointel by the Amir Afkhidu". (*)

A month later the Aluwa diary of the 1sth May, unler the title "Russian Activity in Luristan" adls that

"nothing further has been heard of the Russian and his interpreter who were travelling ostensibly examining the places devastated by the earthquake". (*)

The destruction caused by the earthquake in the lower part of the Silakhor Valley was indeed very great and it is vividly described by member's of the Russian mission. They found that in many villages.

"viltually nothing remained above gromel. We could find there not a single surviror, of whom one could enquire details about the disaster; only packs of dogs and ravens tearing at the corpses disturbed the silence of the ruins. Only in a few villages some inhabitants could be found, living in huts which escaped destruction; the majority of the Lurs and Bakhtiaris fled even as far as in the districts of Isfahan, trying to find a possible aborle in the villages untouched by the eathquale. . What is even worse, nearly all romestic animals have perished and now, lespite the early sowing season and plentiful spring rains, noborly can undertake any field work without draught animals" (5is).

The disister gave rise to curious tales, not all of them completely devoid of some linth, and to exggerated accounts of the effects of the earthquake. Persian reports indicated that.

(*) I. O./Confidential Diary Ahvaz no. 850.1017 


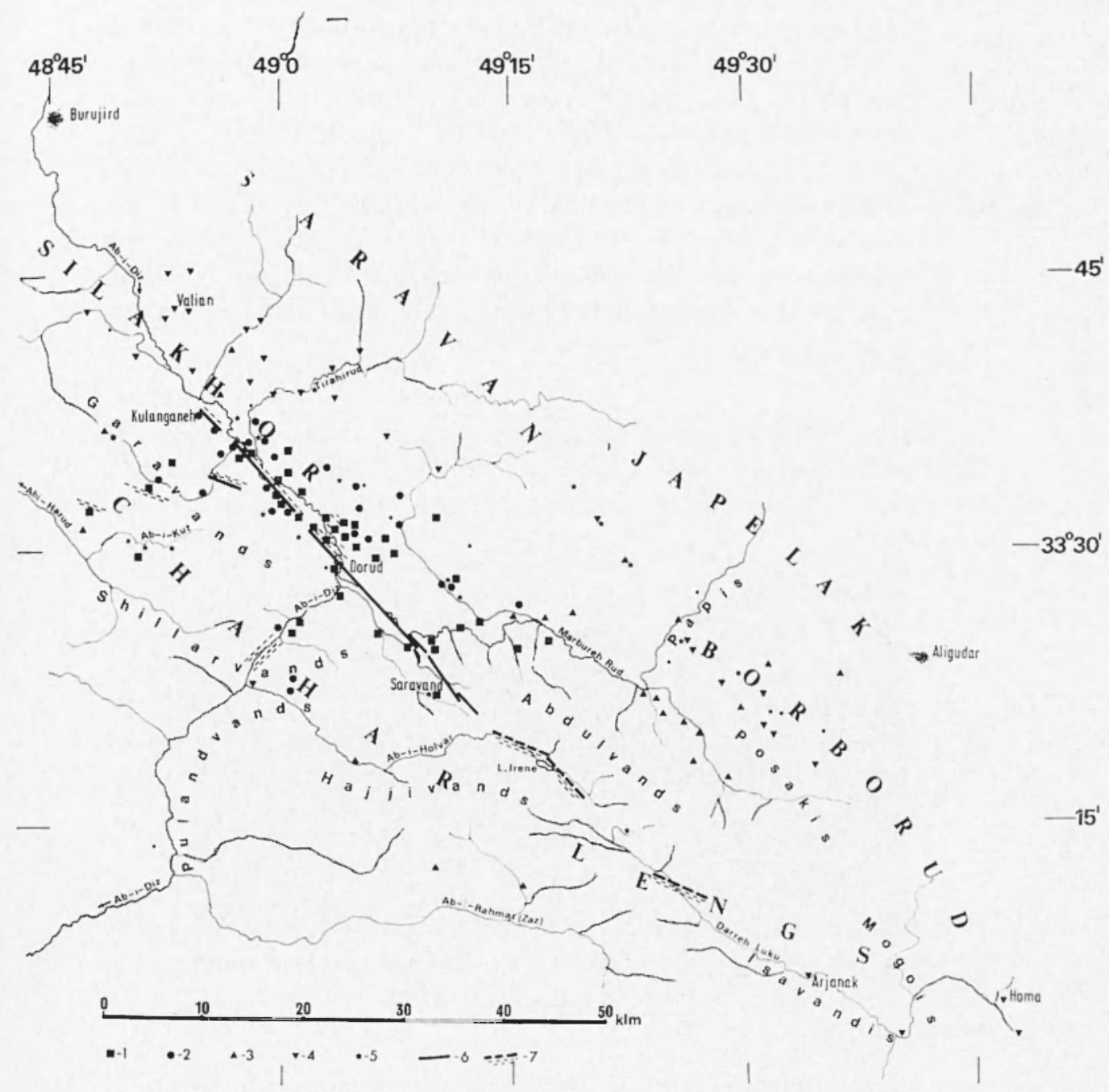

Fig. I - Distribution of damage caused hy the Silakhor earthulake of the 23rd January 1909. 1: Location of villages totally destroyed with more than $50 \%$ of their inhahitants killed; 2: villages totally destroved with less than $50 \%$ casualties; 3 : villages heavily damaned or destroyed without casualties; 4 : localities and villages that suffered some damage; 5: modern settlements; 6 : abandoned sites: 7 : fault-break associated with earthquake;

8: regions of extensive ground deformations, landslides and rockfalls. 
"over 40 villages, from Chalan Chulan eastwards are sair to have been destroyed; in most cases only two or three men or a single fowl are left alive. Villages are said to have 'gone down' and totally 'disappeared', and tales are told of a river which flows into a chasm, and of an old fort with walls 30 feet thick which has been precipitated borlily from its place for a distance of a 'maidan-i-asp' (say 600 yards) and been deposited in the bed of a river" $\left({ }^{*}\right)$... "In the district of Mavar-Zarrin (**) hundreds of families and all their animals belonging to Hajjivandis were overwhelmed by the fall of a mountain which bulierl them" (58).

Consul Nikolski describes the dreadful sanitary conditions in Silakhor and stresses the danger of infectious diseases originating there among the survivors, and then sprearling over the whole of Persia. He says:

"The suffering of the people is further aggravated by the rlearlful sanitary conditions in the countryside destroyed by the earthquake. The corpses of people and animals, in places hardly covered by the ruins, in places dug out by the pack of dogs, decay in the warm rain and under the hot rays of the spring sum and infect the surrounding atmosphere over many versts" $\left(\begin{array}{ll}51 & 53\end{array}\right)$.

He recommends that the Government should undertake immediately full measures required to make these areas fit for habitation again and to prevent the spreading of infectious diseases which might originate there. In his letter to the Charge l' $\Delta$ ffaire e in Tehran, E. V. Sablin, he says:

"The destroyed villages remain in the same drearlful state in which the earthquake left them. Noboly is attending to the dead, and nobody extends a helping hand to the living, who face death either from diseases or from starvation", (51).

(*) I.O./I.C.R/L/P \& $\$ / 7 / 228$ no. 713 Confidential Diary 70 ; ef. F. O. 248,968

(**) Presumally the nountainous region beyond zarrin, between Dorreh Juku and Al)-i-llolvar. 
He suggests to Sablin that the Mission in Tehran should organise a collection of money among Europeans in the capital and that Russian consuls in Persia should also contribute. He goes on to say that:

"As there is no hope whatsoever that the Persian Government or people are able to ofler any assistance to the victims, . . I am prepared to shoulder the distribution of these funds among those in real neerl. Perhaps, the Crerlit Bank of Persia will be willing to take part in this mission of mercy and agree to transfer to me free of charge these donations through Mr. Agam, their correspondent in Kermanshah"'( $\left.{ }^{51}\right)$.

Nikolski also made an appeal to the Ministry of Foreign Aftairs in St. Petersbourg suggesting the formation of a Central Committee for

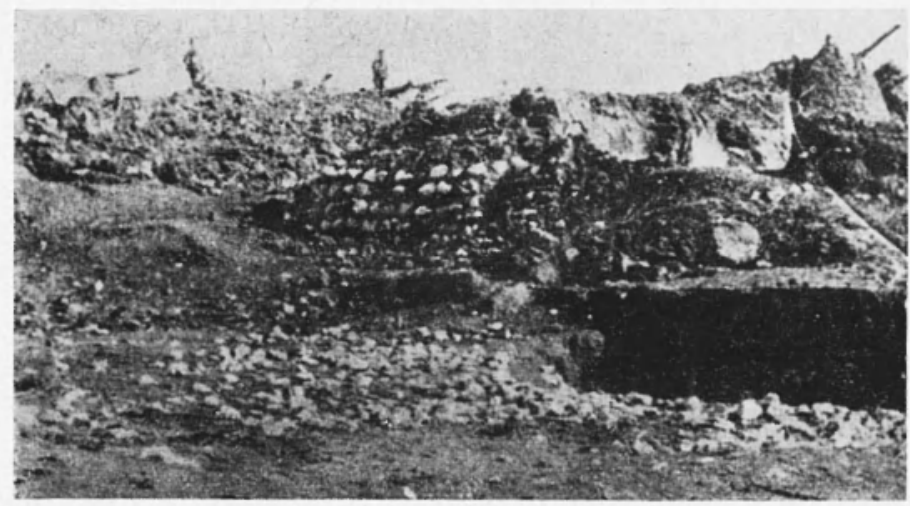

Plates 3 - The village of Sangar photographed by Sukhenko in February 1909; looking west.

assistance to the victims of the Silakhor earthquake which he suggests could be organised along the same lines as the St. Petersbourg-Mesina Fund which was established a few months earlier after the Mesina earthquake in Italy of the 28th December $1908\left({ }^{53}\right)$.

To what extent Nikolski's appeal materialised we have been unable to find. We know that Is. V. Sablin, the Russian Charge d'Aflairs in Tehran, offerer himself to chair a relief committee, but there is no evidence that such a committee was ever formed (58). There is evirlence however, that in April 1909 a fund for the victims of the Silakhor earth- 
quake was opened in British Consulates. The Sistan Consular diary for the 12 th June shows that:

"A Luristan earthquake fund was opened in Birjand some two months ago. The Hashmat al Mulk, Shaukat al Mulk and a few others, including Mr. Howson, assisted in the collection of funds. Mr. Howson acted as treasurer and kept the accounts; and a sum of 6,299 Krans has now been remitted to Tehran"' (*).

However, the Luristan Earthquake Fund was ill-fated; in the Sistan Consular diany of a few days later, we rean that

"His Britamnic Majesty's Minister has wired that no (Luristan) Fund exists in Tehran ... and that the subscribers wish to have their money back" (**).

As a matter of fact on June 2nch, Sir G. Barcley sent the following telegram to Fímanshah $(* * *)$ :

"Do you know anything about Luristan Eanthquake Fund?

I have received nearly $\underset{\sim}{f} 100$ from Sistan, for this purpose". He does not seem to have been answered on this matter. It does at least seem, however, that there was a certain amount of interest in this earthquake, once news of it reached Tehran, apparently in the second week of February. From the sequence of corresponflence, it looks as though the earthquake would have gone almost unnoticen and would almost certainly not have been recorded by the British representatives in the area, had not the Tehran Embassy pressed for news.

So, with the exception of two short poems composed by natives of Burujird and Kermanshah which lament the victims of the Silakhor earthquake (42), we coulil find no other evidence of concern about the situation created by the earthquake in this remote part of Persia (***;s; $)$.

(*) $1.0 .1 \mathrm{~L} / \mathrm{P}$ \& $\mathrm{S} / 7 / 230$ nos. $22 / 1048$ \& $23 / 1113$.

(**) 1.O.T.P \& 87230 nos. 221048 \& 231113.

$(* * *)$ F.(1. 248968

(****) One of the reports is accompanied hy six photographs, two of which Plates 3 and 4 are reproduced here (5l). Another report is aceompanied by four plates (in glass) showing the damage in four villages, too faint now, damaged by time to give good prints (58). 
One of the important question that remained manswered in our earlier paper (41) was that of the actual extent of the meizoseismal area of the 1909 earthquake, particularly to the south of Bahrain. From Shtelling's report $\left.{ }^{33}\right)$ it was evident that owing to the premat ure recall of the Russian mission to Kermanshah, information about clamage in the region south of Bahrain (nodern Dorul) was incomplete. This is confirmed by Nikolski, who, however, makes it quite clear that clamage did extend beyond Bahrain. He says that:

"from my Agent's words, based on information he received, the earthquake of the 10th of January (old style), while moving in the direction of Isfahan, has destroyed many villages among the Bakhtiari Haft-Lengs. The area of destruction apparently extends to Isfahan itself, the number of destroyed villages being up to 128 along the track from Burujird" (59, 52).

He then goes on to describe the damage to 27 villages visited by his mission in the Silakhor Valley to the north of Bahrain (51). In his report, however, Asad Allah Mirza adds the description of damage to another 31 villages belonging not only to the Silakhor Valley but also to Razan in the northwest and to Japelak and Borborud to the southeast of Silakhor, mainly inlabited by Bakhtiaris of the Chahar Lang

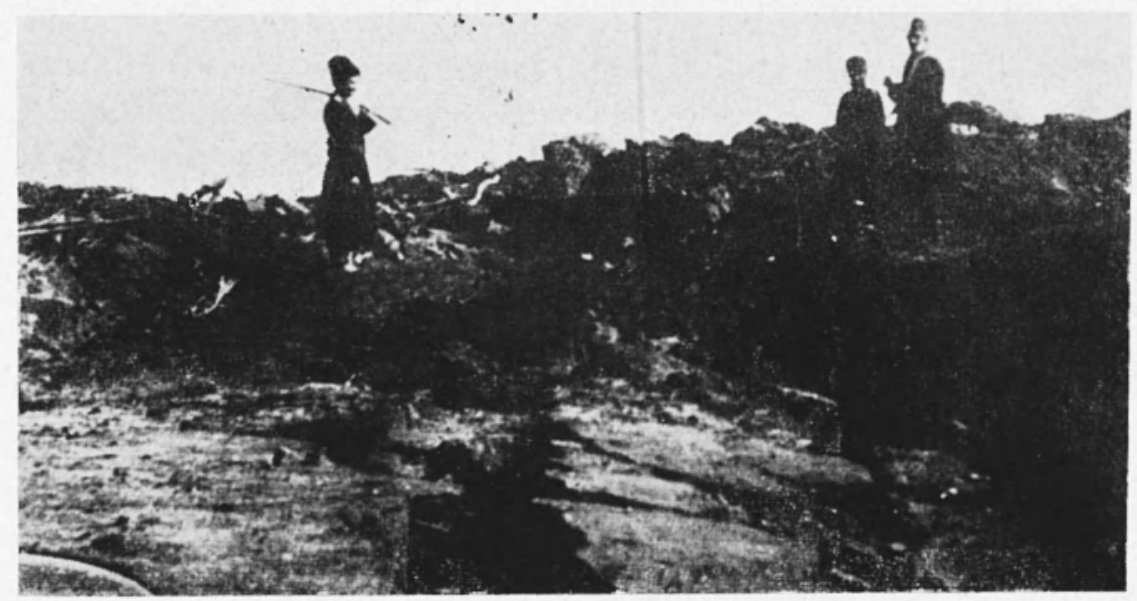

Plates 4 - The ruins of sandargan as seen by Sukhenko shorty after the carthequac; note ground deformations in the foreground, viewed from the north. 
tribe (43). This report confirms that damage extended woll outside the Silakhor Valley, a fact which is attested by another valuable somre of information ( $\left.{ }^{58}\right)$ which gives a detailed description of the losses sustained by valious tribes and sub-tribes of the Chahar and Haft Iang Bakhtiaris as far south as Ioma and Arjanak. This document seems to have been prepared as an appenclix to a Persian intelligence report dealing with local revenues and taxes and on the general tribal situation in the area after the 1909 eartiquake.

Table 1 gives a summary of all the information available regarding the effects of the silakhor earthquake of 1909. This table includes information from published and unpublished somces as well as data collected from local people during the author's field trips in the region 64 years after the arthquake. Figure so shows the distribution of damage as well as the approximate location of tribal gromps in 1909.

As already noticed ("11), damage was most serious in the densely populated Silakhor Valley where many Lum and Bakhtiari Haft-and particularly Chahar Langs, perished. The Chahar Iangs belong to a division of the Bakhtiaris, a tribe of nomals the majority of whom migrate anmually between their summer and winter quarters, and whom in 1909 should have been confined mainly to the mountains and high valleys between Silakhor and Isfahan ${ }^{(48)}$. However, well before 1900, a good part of the Chahar Langs had already become sedentary, dwelling in small villages scattered in the momtain valleys and plains, chiefly to the west and sontheast of Silakhor $\left({ }^{4+, 18}\right)$. The other main division of the Bakhtiaris, the Haft Iangs, partly settlers and partly nomads, occupied the region located roughly to the southwest of the Chahar Jangs with ill-defined and fluent borders between the two tribes, Figure jo.

The 1909 earthquake caught most of the Chahar Iangs in their winter camping gromols and villages, killing a large number of them; landslides and rockfalls added to the destruction, particulary of their animals. Tf we trust a contemporary account of the disaster, the subtribe of the Hajjivands was decimated, losing 300 families and all its animals. Ialf of the Abdulvands who lived on the flanks of ShuturunKuh were killed or perished in the cold in their winter quarters; survivors were forced to abandon the mountain pastures which after the earthquake were said to have becone dry "and strewn with grey ash". The Posaki tribe lost about 100 familes "who were buried nuder the mountains that fell on their winter villages"; survivors were obliged to abandon temporarily their pastures and hamlets on the southeast 


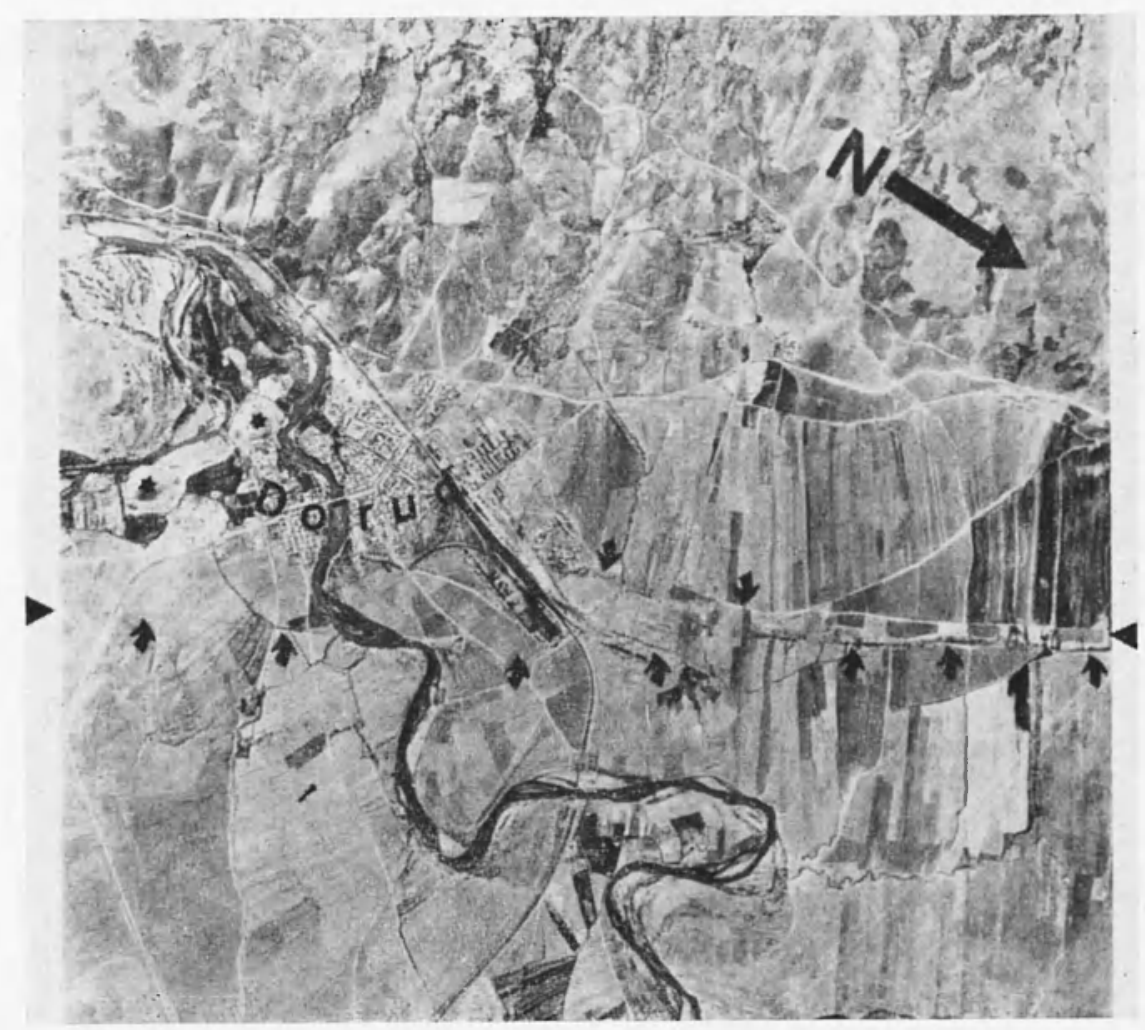

Plates 5 - derial view of the fault-break associated with the 1909 earthquake at Dorud.

slopes of Shuturun-Kuh and seek refuge further south among the Mogois. The latter suftered few casualties but some of their fortified villages were ruined as far south as Homa. In this region rockfalls killed a small number of Isavandis and caused the mountain track to the north through Mavar-Zarrin to be closed; at the latter locality hundreds of Hajjivandi families and their animals perished. To the northwest of Silakhor, in the Razan-Rangrazan (*) area, about 100 families belonging to the Garavand and Sagvand(?) tribes perished together with all their animals and stores of grain. After the earth-

$(*)$ In $(41)$ the region of Rangrazan is wrongly identified as that near Razan on the Abe-i-Diz. In fact Rangrazan oceupies the northwestem part of the $\lambda$ b-i.Kut valley southwest of Razan. 
quake the tribe of the P'ularvands of the Khanabad region, although they do not seem to have sulfered any great loss, abandoned some of their tribal territory and moved across the Ab-i-Diz to the southwest cansing considerable unrest in the region along the Khorramabal route $\left({ }^{58}\right)$.

Although it is afficult, almost impossible to establish toclay the exact boundaries of these tribal areas as they were in 1909 , it is obvious that the earthquake played havoc among those tribes who liver on either sirle of the Shuturum-kuh for a distance of at least 40 kilometres to the southeast of Bahrain. The contemporary accounts alrealy mentioner testify to the destruction of about 1000 households, inclurling those of tribes in the Silakhor Valley, notably of the Bailanivamdis. Assuming that the average number of people was eight to a household $\left({ }^{44}\right)$ the total number of casualties should have exceeder $8,000\left({ }^{*}\right)$, a figure most probably grossly exaggerated by the author of these accounts from which Sablin (58) drew this information (**). However, in the Silakhor' Valley alone, 1,703 people were reported killed "excluding women and children and the inhabitants of villages and settlements without survivors, whose number could not have been estimater even approximately" (51).

Some of the earthquake efferts mentionerl in these reports are interesting as they allurle to faulting:

"In many placed (past Zargaran) one could see land-slicles and cracks in the gromul: in depth these cracks did not exceed 3 arsin (****), their wilth varied between several versok (***;) and 4 ansin; the length of some eracks extenderl to several rersts $(* * *)$. The appearance of the rocks found on the vertical faces of the crackis tencls to suggest that some hot water and steam came from underneath polishing them" ("11).

"Khosrauabarl, a large village belonging to Hajj Aqa disintegrater; the ground openerl up in many places tearing houses apart, swallowing walls and water coming out of the ground floorled the ruins... (hoqa Abrar, the property of 'Ali Khan was divided in two for him by the earthquake; one part for his

(*) Bell (I889) reckons cach Bakhtiari family at five mombers; Bishoj, (189) al aight.

(**) In $188+$ the Chahar Langs numbered about 12000 fantilies and the Haft Langs 11000 in all $(4.5)$.

$(* * *) 3$ arsin $=84^{\prime \prime}$; vorshok $=13 \cdot 4$; vorst $=3500^{\circ}$. 
elder son Mirza Massud and another for Hussain Aqa(?) ... Cheshmeh-ab was turned upside down when the earth split in two from east to west" ("58). "A river now flows into a chasm".

A photograph taken by the Russian mission near the northern edge of the village of Sandargan testifies to considerable ground deformations, Plate 4. Iuch of this information about faulting has been already substantiated (41); faulting did extend from near Kalanguneh to south of Saravand, a distance of over 40 kilometros. To the southeast of Saluvand there is no explicit evidence of faulting associated with the 1909 earthquake. There is, however, a tradition suggesting that apart from Lake Irene (*) there were two more, smaller lakes created by the 1909 earthquake and that their water having found an exit in the chasms in the ground caused by the earthquake, gradually disappeared. This is very reminiscent of the local tradition related to Morgan by Silakhoris in June 1891, i.e. that very long ago the two valleys of Silakhor were a lake and that the Prophet having eut with his sword the mountains, the Tang-i-Bahrain was formed and the waters flower from there towards Dizful on the Ab-i-Diz(ful) $\left.{ }^{(49}\right)$. As a matter of fact, the Prophets' sword, the major geological fault that runs through this Tang and its 1909 dislocation all allude to earlier earthquake events in this part of the Zagros.

There are some allusions to the past earthquakes and large scale landslides in the valleys to the north and sonth of Lake Irene and in

$\left({ }^{*}\right)$ Part of the area affected by the 1909 earthquake was visited before and after that year by a few European travellers, i.e. Jayerd in 1840 (46), Loftus in $1856(47)$, Bell in 1884) (45), Sawper $\&$ Biship in $1890(57,44)$, Morgan in $1891(49,50)$, Strauss in 1903 (59) and Wilson in 1911 (36). They went over the same ground, but the names of villages and mountains differ much, depending with whom they travelled, i.e. Luris, Bakhtiaris, Persians from the north or local guiles who gave them the nimes in use among themselves.

Lake Irene was first described by Sawyer $(56,57)$ : "To the northwest" he say's "at the inner foot of the shuturun-kuh, is another lake as yet muknown to the world at large... This lake is sait to have been seen by a European a few years ago, an employee of Hotz \& Son. Really nameless, even locally... it might suitably be known heneeforth geographically as lake Irene... after ny little daughter'. Shortly after Sawyer, the lake was risited and photographed by Morgan $(49,50)$ who ealls it Lake Gahar or Ghahar. Strauss (59) calls the lake Ab-i-Keher, while we found that local people call it Ab-i-Mlianech or Miunah. 
the Darreh Lukn even beyond Arjanak. Before the 1909 earthquake, Sawyer, travelling in 1890 between Lake Irene and Saravand remarks:

"The whole of the valley to the south of the Shuturum-kuh has the mark of death about it - uninhabited, still, and full of signs of the reputed earthquakes... there can be no doubt that voleanic action has here been most recent" (56).

Apparently, he refers to the huge landslide that in historical times blocked the valley creating Lake Irene, originating from the steep slopes of Shuturum-kuh where the landslide searp coincides with the extension to the south of the fault-break associated with the 1909 earthquake. Referring to the upper reached of the Darreh Luku, Sawyer says:

"One valley, especially well watered, with plenty of flat spaces for cultivation, near which are the remains of Ancient Armenian stone villages, is now deserter on account of the frequent earthquakes that heppen, the effects of which are seen by the masses of huge rocks sprinkling the lower spurs of the ShuturunKuh (*). Near its centre is a small lake, touching the northwest end of which is a small volcano to all appearances of but recent extinction (sic)" (56).

It is very probable that the frequent earthquakes to which Sawyer refers include the earthquake of July 18503 which occurred about 50 kilometres to the southeast of Lake Irene, in the Feridan and Chahar Mahal districts. From contemporaly accounts, mainly Armenian from Julfa, we know that this earthquake devastated the region between Tarun, Akhoreh, Farsan and Chiga-Chor in which many Armenian settlements were ruined and later abandoned. This earthquake, which should have been as large as the Silakhor earthquake, causer some damage in Isfahan and it was strongly felt in Golpaigan. Other, smaller shocks are known to have occurred before and after 1853 in the Lendjan district causing considerable damage to Kert and Akhoreh. It is ruther strange, therefore to read in Nikolski's report that

"By questioning the few survivors, Luris and Bakhtiaris (in the Silakhor Valley) who up till now had never experienced

(*) Rockfalls in this valley are also noticed by Morgan $\left({ }^{49}\right)$ who visited the region a year later. 
an earthquake, and who maintained that to their knowledge there never were any earthquakes in their district, it became clear that the populace was struck by the disaster totally moreparerl, while asleep" (5is).

As a matter of fact, local tradition was and still is full of legends about earthquakes and about their eflects on mountains, rivers and springs of water. It is very curious that those interviewed by the Russian mission in Silakhor did not remember or knew nothing about the destructive earthquake of Feridun which five years earlier seems to have been responsible for the eventful migration of refugee Posekis and Isavandis from the Tarun area, about 70 kilometres to the southeast of Dorud, into Silakhor.

In connection with the 1909 earthquake, the only evidence of large scale landslides and rockfalls comes mainly from local information $\left({ }^{*}\right)$. It is sail that about three farsakhs (18 kilometres) from Arjanak in the Mavar-Zarrin, a large portion of the mountain flanks, measuring at least a farsakh in length, fell into the valley "with such a tremendous impact that it caused the earthquake which ruined Silakhor". Our informant adks that rockfalls continuer for some time keeping those who survived the earthquake trapperl in the valleys: "this calamity stoppen on the day of the death of Hussain (**), after which new springs of water appeared but which unfortunately dried up a few years later".

Also in the Ab-i-Diz gorge, between Cham-Chit and 'Abbir, local information suggests that the flow of the river was arrester by landslides. Elsewhere, particularly on the southwest and south slopes of Kuh-i-Farangi, along the $\mathrm{Ab}$-i-Kut river, landslides and ground deformation caused great clamage causing some of the fortified settlements to be abandonerl.

The shock was strongly felt in Hamalan, Arak (Sultanabad), Golpaigan, Dizful and Zohab. It was felt slightly in Baghrlad, Kifri and Sulaymanieh, Kharput, and Tabriz (?). It was not felt in Tehran, Ahwaz, Bushire and Shiraz.

Long-rlistance eflects were reported from Burujird where 18 inches of water was thrown out of the tank in the Governor's garden by the

(*) F. O. 371713 inos. 9806 and 13665 and F. 0. 249968

(**) I0th MIuharram 1327 a.II $=1$ st February 1909. 
rocking of the ground $\left({ }^{*}\right)$. Water was thrown out of the large natural pond near Arjanak, not only by the main shock but also by an aftershock early in 1909. In Burujird, as well as in Khorramabarl, although the shock caused no rlamage, it was strong enough to cause pots and pans to fall ofl shelves and water to spill out of small containers.

Up to the end of March, at least four shocks were felt daily in the Silakhor Valley. In April, intermittent strong shocks were reporter from the Japelak-Borborud area as well as from the region of Razan, west of Silakhor, the latter shocks being felt in Khorramabar. Some of the aftershocks must have been very strong; in the villages of Gholah and Suran they causerl the total collapse of houses killing a number of marauding Sagvandis (?) who har established themselves in the ruins of the villages. Aftershocks also drove a number of refugees from Silakhor ofl villages in the Japelak district where they had sought shelter after the earthquake. During the three months following the main shock 10 strong ones are reported to have taken place of which 3 had been very violent, the rest of a lesser rlegree (54). The aftershock sequence seems to have enderl late in June 1909 (**k) $^{*}$.

Later in the year, on the 21st September, Sir G. Barcley requester his Consuls in Persia to supply him, for the information of the Seismological Committee of the British Association for the Arvancement of Science, with reports of any earthquake which may take place in their districts $(* * *)$.

\section{Conclusions}

The Silakhor earthquake of 1909 and its aftershocks caused damage. within an area of at least 40,000 square kilometres, which extended from Valian in the northwest to Homa and Arjanak in the southeast, Figure 5. Within this area 8,000 people and thousands of animals were killerl. Damage was particularly heavy not only in the rlensely populaterl valley of Silakhor but also in the sparsely settled areas of $\mathrm{Ab}$-i-Kut and Razan on the northwest and of the mountainous tribal settlements of

$\left(^{*}\right)$ I.O./L/P \& $\$ / 7 / 227$ Political Diary Bushire no. $13 / 647$.

(**) The Kermanshah Comsular Diary for w/e 6 July 1909 states that: "It is reported that there is a voleano in active eruption in the same place where the earthquake took place in February last near Burujird".

(***) F.O. 248/968 
Ab-i-Holvar and Darreh Luku in the sontheast, where many tribesmen perished.

The earthquake was associated with faulting, which extended almost continuously for a distance of t5 kilometres from Kulanganeh on the northwest to southeast of Saravand. Gromnd defomations and landslicles suggest that actual faulting extended further southeast of Saravand into the Darreh Luku valley for another 20 to 30 kilometres. Ground deformations, of monown origin also occurred between the villages of Zhan and Suran on the northeast sile of the Silakhor valley as well as in the region of Kuh-i-Farangi in the Razan area. Much of the 1909 faulting, although today in places heavily eroded, is still visible on the gromul, and can be seen very clearly on aerial photographs along a length of at least 10 kilometres. (Plate 5 shows an aerial view of the fault-break near Dorull).

The Silakhor earthquake was followed by a very long sequence of aftershocks which lasted for live months. There is some evidence that most of the stronger aftershocks occurred on the northwest and sontheast ends of the meizoseismal region, and that they added to the damage done by the main shock which ultimately covered an area of 10,000 square kilometres.

This paper shows that given certain conditions it is perfectly feasible to study an earthquake that occurred three-quarters of a century ago in a remote pant of the Sear East. Also, it shows that there are many large earthquakes which, because of lack to interliciplinary efforts to study such events, they have remained hitherto little known or totally unknown. The case of the Silakhor earthquake makes one to suspect that many other, more recent and older earthquakes might still be available for study from published and unpublished dociuments and from field work. 


\section{Noles on Table I}

Table I lists village's, nomad settlements and camps as well as fortified encampments which were affected by the 1909 earthquake. For each village or nomad camp Table I gives the name, with alternatives, and the district in which the village is located, the major tribal group and the name of the landowner. The districts affected are:

\begin{tabular}{|c|c|c|c|}
\hline Bardeh Sareh & $=\mathrm{B} \Lambda \mathrm{R}$ & Kagheh & $=\mathrm{KAC}$ \\
\hline Borborud & $=\mathrm{I} 3 \mathrm{OR}$ & Qaed Rahmat & $=Q \Lambda I)$ \\
\hline Chalan Culan & $=\mathrm{CIII}$ & Razan & $=\mathrm{RA} /$ \\
\hline Jalvand & $=\mathrm{J} \mathrm{AI}$ & Silaklıor & $=\mathrm{SII}$ \\
\hline Ileshmetabad & $=$ IIISS & 7allaqi & $=7 \mathrm{AI}$ \\
\hline Japelaq & $=\mathrm{J} \Lambda \mathrm{P}^{\mathrm{P}}$ & $\begin{array}{l}\text { Zaz va Mahru } \\
\text { Zhan }\end{array}$ & $\begin{array}{l}=\% \Lambda \% \\
=\% H N\end{array}$ \\
\hline
\end{tabular}

The following tribes and sub-tribes were in the epicentral area:

$\begin{array}{llll}\text { Abdulvauds } & =a b d & \text { Papis } & =p a p \\ \text { Garavands } & =\text { gar } & \text { Posakis } & =\text { pos } \\ \text { Il ajjivands } & =\text { hij } & \text { Pulandvands } & =p u l \\ \text { Isavands } & =\mathrm{isv} & \text { Shillirvands } & =\text { shl } \\ \text { Mogoi } & =\mathrm{mog} & & \end{array}$

Iand-owners whose property was lost in the earthquake were:

1. 'Abd 'Ali Mirza.

2. 'Ala al Mamalik

3. 'Ali Khan

4. Asad Khan

5. II ajji $\Lambda_{q \mathrm{a}}$

6. Hajji Aqa Fakhr al I)in

7. Il ajji Aqa Ghulam-i-IIusain

8. IIajji Mansur al Mamalik

9. II ajji Mizza Muhammad II usain

10. Ilajji samsam al Mamalik

11. Imam Juma

I2. Inayat al Mulk
13. Mirza Kulli Khan

14. Mirza Muhammad 'Ali Khan Mustanfi

15. Muhammad Khazin Khan

16. Qismat al Jauleh

17. Sabad as-Sultaneh

18. Sardar Mukarran

19. Sartip Akbar Khan

20. Sipeh Kikdar

21. Zill-i Sultan

22. Local Ilojjas

23. Local Khans

24. Tribal property

Jamage is abbreviated as follows:

1)]) = total destruction with more than $50 \%$ of the inhabitants killed,

1)1 = heavy damage with less than $50 \%$ of the inhalbitants killed,

I) = heavy damage without calsualties,

d $=$ small damage. 


\section{'T $\triangle \mathrm{B} \mathrm{J}, \mathrm{E} \quad \mathrm{I}$}

'Abhid

Abikut

Afraneh

Alimatabad

Ahmatabad

Albarabal

'Aliabad

A mirabal

Ancroslitel

Anuj

Arjanak

Ashrafabad

Azna

Barakhuni

Bahroin

Bahramabad
DI) ('Abbad, KAG-gar-23) Tribal sedtements heavils damaged and 25 people were killed; rockfalls

DD (RA\%-grar-24) Fortified sedtements demolished; many animals killed; landslitles; springs of water dried up.

d (Afranvadeh, SlJ-23) All houses cracked, a few walls foll.

d (CHL-23) Minor damage; change in yield of spring water.

D (BOR-pap-23) $\triangle$ fow houses collalpsed killing 2 people.

D1) (HES-22) Amost all houses were destroyed and 6 people were killed; gromd doformations, slumping and lurching.

d (BAR-23) Minor damage.

DDD (Mirabad, KAG-8) Totally destroyed: 76 people were killed in the eitadel and $4+$ in the village; 510 animals killorl; gromud cracks and mud voleanoes.

DDD A wateh-tower near Angoshtel was ilemolished.

d (BOR-shl-24) The fort was badly damaged; no ('asualties.

d (BOR-is-4) All houses and citadel cracked; rockfalls in the vicinity; water sloshed ont of pond at $\mathrm{Ab}$-i-jan.

1) (Agrirofabad, BOR-pos-23) The fort was destroyed and many houses were ruined, a few animals killed.

1) (KAC-23) a number of houses destroyed; no ('asualties.

DID) (KAG-3) Totally destroyed and abandoned for some years; all animals perished and 20 people were killed; gromd deformations, mul voleanoes.

DDD (Dorud, KAG-10) Totally destroyed inceluding the fort, two mosques, public bath, Imamzadeh and surrounding houses; in the fort $2+$ people were killed and another 130 in the village; landslides and rockfalls from the hill on which the fort stood.

D1) (KAG-21) Almost totally destroved: 13 people killed; village abandoned for sometime and 
Balabashi

Balraftab

Barzan

Baytuu

Borjla

Budinelt

Bunkabad

Chahah Cheshmeh i

Chalan Chulan

Chamanar

('heshmeh samanjoll

Cheshumedt

Choga Bahram

chocgal dhelar

(hoqa I) m

churug

Darah Astanch

I)arband

D)armiyan

I)arrele Ashar rehuilt as Olia and Sofla; new spring of water appeared after earthquake.

d (SIL-22) Allegedly damaged.

I) (\%A\%-hjj-2t) Many animals in nomad camps perished from rockfalls: a ruined fort collapsed.

I)I) (1I LS-1) Totally destroved; not a single person survived.

d (SIL-23) A few animals killed; minor damage.

d (BOR-pal-23) Khan's residenee collapsed; no (asualties.

DDD (HLA-23) Totally destroped: no survivors.

I)I) (HLS-23) Totally destroyed; 180 people killed, few survivors.

d (BOR-hjj-2t) Springs of water dried up: landslicles; no damage to nomad camps on the alrat.

d) (1HL-23) $\mathrm{d}$ fow houses were damaged.

I)I) (Chamnar, HES-16) Totally desteyed : very few survivors; landslides and rockfalls killed a new nomarls in camps south of Chamanar in the Marburreh valley.

I)II) (Ah-i-cheshmeh, KAG-l(1) All adobe houses of nomad sedtement destroyed, killing 13 people: landslides.

I)I (Ab-i-cheshich: DAL-l0) All forts in the Ab-iKut valley collapsed: changes in springr water.

I)I)I) (KAG-2) Totally destroyed; feW survivors.

DI)J) (KAG-3) Totally destroyed; 150 people and all animils killed ground deformations and slumping,

I)I) (II ES-23) Heavily damaged, many people killed.

d (Qurmq, SIL-23) i few houses collapsed, no (asualt ies.

DID) (IIES-hjj-23) Razed to the ground; ont of 500 people 2 is were killed together with all animals; rockfalls, gromel deformations: springs dricel up temporarily; new springs appeared.

I) (BOR-palp-11) A fow houses collapsed; no casualties.

DI) (IIES-6) dll houses destroved or damaged beyond repair; 10 people killed, village temporarily aluandoned.

1)ID) (HES-23) Totally destroyed; few survivors; landslides and ground deformations. 
Darreh Chenar D (ZAZ-hjj-24) Nomad camps overwhelmed by rockfalls; a few ruined houses collapsed.

Darreh Takht D (BOR-pap-24) A number of louses were ruined; no casualties.

Daryab DD (Darab, KAG-19) All houses ruined; a few collapsed killing $1+$ people.

Daulatabad d (Bor-23) A few people were injured; minor damage.

Deh Agineh

DDD (Dehayneh ve Yusufabad, KAG-8) Razed to the cround; 70 people and all the animals of the village perished; abandoned temporarily; ground ileformations, change in spring water.

Delinau

DDD (ZHN-5) Totally destroyed; 130 people killed; ground deformations, mud voleanoes; abandoned temporarily.

Deh Qadi

D (ZAZ-hjj-24) At this locality many nomads were overwhelmed by rockfls and aralanches (?)

Dinarabad

d (SIL-23) A few houses were ruined; no casualties.

Dukhamarin

(I)

(KAG-23) Minor damage; changes in spring water.

Emerat

D (ZAZ-hjj-24) In this region a fortified settlement was ruined and many families of nomads were killed together with their flocks (by avalan(hes?).

Fimanabad

DDD (KAG-shl-8) Totally destroyed and abandoned; 54 people killed with all animals, an old fort was ruined; ground deformations.

Gavkusheh

DD (Gavkoshteh, Gavkujeh, HES-16) All houses detroyed killing 25 people.

Gesheshabad

DDD (RAZ-gar-9) Totally destroyed and abandoned; two towers near by, in the Ab-i-Kut valley were destroyed; springs of water turned salty.

Ghaziabad

d (?-shl-24) Water burst out of the ground flooding the village.

Gholah

DDD (Golgurchah, ZHN-24) Razed to the groumd (by an aftershock?).

Golbahar

d (BOR-24) Ruined, without casualties; abandoned and rebuilt.

Gorji

I) (Gershezabad, Ghurdji, JAP-pap-24) An old fort and 20 houses collapsed without casualties.

Gushch

d (KAG-23) Suffered some damage (by an aftershock?) 
Gishehpul

Hamliyan

II asak

II a voli

II ayclerabad

Hesjmetabad

Iloma

II usainathad

Juy Asiah

Kaliriz

Kakah

Kalehjangi

Kalch Killeh

Kanendan

Kenikulı

Khamahad

kiert

Khosraumireh

Khostaubad

Kulanganel

Kuliabat
I) I) (KAR-19) Partly destroyed; 23 people and all animals killed; ground deformations.

d (HES-22) A few houses collapsed without casualties.

d (/AI,-24) Springs of water dried up; minor damage to houses.

d (BOR-mog-24) An old fort collapsed; minor damage to houses; water gashed out of the ground.

d (SIJ-gar-23) A few houses were damaged.

I) (HES-23) Houses collapsed killing animals.

d (BOR-mog-13) Springs of water in the clistrict chied up; part of the wall collapsed: no casualties.

I)I) (KAG-10) Most houses collapsecl killing 24 people; ground reformations.

I) (BOR-pos-22) The fort and citadel collapsed. d (SIL-23) All houses damaged.

D) (Kushgak, Kaskah, BOR-23) 10 houses were clestroyed.

d) (Qal'eh Jahangir, ZHN-23) All houses damaged.

I)I) (Kuleh-Kuleh, Kalkaleh, JAP-16) Many houses collapsed killing 25 people.

1) (Qal'eg Kamendan, BOR-bos-22) All houses damaged; the citadel collapsed. Many nomats were killed by rockfalls near this place. In the mountains to the southwest of the fort many fumilies of the Abclulvand tribe perished.

D) (BOR-abd-24) A new spring of water appeared after the carthquake; damage to local houses was heavy.

d (ZAZ-sh1-24) A few alohe houses were damaged.

a (JAP-pal-23) Partly abandoned at the time of the earthouake; old ruins collapsed together with an old Armenian huilding. Near Mas'udahad landslides blocked the pass.

1) (BOR-shl-24) An old castle collapsed killing a few people.

DT) ( $\mathrm{KAG}-5)$ Destroyed; 6 people killed, abandoned for a few years.

I) (KAG-22) $\Lambda$ few houses collapsed without loss of life.

1)DD (Kole Abad, Golabad, RAZ-gar-6) Totally destroyed and subsequently abandoned; 30 people 
Kinyabad

Iaban

Mahmudabad

Maliehdin

Malekabad

Mirzan

Mir Ahmadi

Miyan Ruyan

Murabak

Nasiraldin Pain

Nasiraldin Bala

Nushli

pirabad sofla

Pirabad Olia

P'ishkashan

Qal'ch Qaed killed: many nonads in the Rangrazen area perished and a number of forts were ruined. springs of water dried up and pastures dried up).

I) (KA $\mathrm{K}-23)$ All houses danaged beyond rejoir; ground fissures and mud volcanoes; no casuaties, village abandoned for two years.

DDD) (KA(r-14) Twin village of Iavan Olia and Sofla destroyed eonpletely including the ritadel; 25 people were killed together with all cattle; ground deformations and mud voleanoes; underground water flooded the spales between the two villages.

1) (JAP-22) Many houses were ruined; no casualties.

d (ZAL-mog-13) $\Lambda$ few houses and the Imamzadeh were ruined; no casualties.

1) (BOR-shl-24) All houses were damaged; no casualties.

I) (KAG-10) Qal'eh Mirzai collapsed together with many houses lilling 20 people; near-by Baba Mirzai was razed to the ground where 30 people were killed; abandoned for some time and resettled later by fanilies of Baba Khuni. Ground cracks and mud voleanoes.

I)I (?-19) 11 people killed; no trace of this locality.

I)DD (Miyan Rudan, Miurudon, JAP 21) Completely destroyed; not a single survivor left; landslides.

(1) (KAG-23) All houses damaged.

IDDI) (ZHN-2) Razed to the ground; 200 people killed together with all the cattle.

DDI) (ZHN-2) Totally destroyed; all 154 inhabitants and their animals lilled; ground deformations.

d $(\mathrm{KAG}-23) \mathrm{A}$ few houses collapsed; no casualties.

DDD (ZHN-7) Totally destroyed and 60 people were killed; all cattle perished; village abandoned for two years.

I)I (ZIIN-7) Out of 500 people, 4 were killed; all houses destroyed or damaged beyond repair; many animals killed.

DI) (Pushkestan, KAG-23) lleays damage; 30 houses collipsed killing 14 people.

DDI) (QAD -23) The fort was destroyed and 58 nomads were killes in the finl Darreh region near Qal'eh Qaned. 
Qal'ih Rustam

Qalloh Qanim

Rakan

Rangrazan

Razan

Sanbadan

Sanbal

Sandargan

Sangar

Saravand

Shahpir Vali

Shalmakan

Shakarabad

Shengran

Shur

Sireli

Siyahkaleh

Siyaval
1)1) (JAP-abd-16) Completely destroged; few people escaped muhurt; landslides; new springs of water.

I)I) (Q:1)-12) Razed to the ground together with near-by forts on the $A b-\mathrm{i}-\mathrm{K} u t$; few nomads ('scaped unhurt.

1)1) (Raikan Olia \& Sofla; KAG-pul-23) Totally destroyed; large scale landslides and rockfalls.

DI)1) (1) HA-gar-18) Hundreds of families of Varavandis perished in this region; at Rangrazan 70 people were killed and the banks of $\mathrm{Ab}$-i-Harud slumped;

1)1) (RAZ-gar-24) All houses collapsed; no casualties.

I)1) (Sureh Vardi, Sunabeddin, HES-10) All houses collapsed killing i people; ground deformations.

1)1)1) (?-10) Razed to the ground; 50 people killed; no survivors; location of site not known.

1)I) (KA(-12) Almost all houses collapsed: 20 people killed; village rebuilt by survivors of Baba Khuni.

1)I)I) (KA(G-8) Totally destroyed; out of 400 inhabitants only 3 survived; all cattle killed; in citadel which collapsed, 42 people were killed; Sangivareh district abancloned.

1)1)]) (HLS-abd-23) Completely destroyed and 130 people killed; rockfalls killed many nomads in the vicinity.

1)1)1) (?-24) Totally destroyed: abandoned?

1) (ZAZ-hij-24) many houses collapsed; no casualties.

1)1)1) (KAG-24) Completely destroyed; abandoned for two years.

1) (BOR-pos-23) In the village and in the vicinity many nomads perished.

d (ZHN-24) Ground deformations; a number of house's were damaged.

D)1) (Al-Sireh, Lasureh Olia \& Sofla, HES-23) Completely ilestroyed; $50 \%$ of the population and 100 of the caltle perished landslides and rround deformations; a new spring of water appeared for a short time after the carthquake.

J)1)1) (KAG-12) Totally destroyed; 194 people and all eattle perished; ground doformations.

1)1)I) (KA ( -23) Totally destroyed; 80 people killed. 
THE SEISHCITY OF IBAX. THE NILAKHOR (IURISTAN) LARTIQCAKE ETC. 425

sivaleh

Sultanabad

Sultan Malnumul

Suran

Tanurdar

Talqiabarl

Tiyan

Turshab

Valian

Yazdgirt

Yusufabarl

Kan

Zargaran

Zarnan
D) (BOR-isa-24) A considerable number of nomads perished in the region.

I (BOR-24) I few houses were ruined.

DD (?-24) Heavily damaged: 15 people killed.

DDJ) (Sirun, Suzan, IIES-17) Completely destroyed; many lives lost; ground deformations.

DD (Tanur-darreh, Tarudar, KAG-5) Almost all houses collapsed killing 15 people, a spring of water dried up permanently.

DDI) (KAG-23) Completely destroyed; 200 people lost their lives; ground cracks and flooding of the alrea.

DDI) (Tiran, JAP-20) Totally destroyed with great loss of life; landslides.

DDD (HES-15) Completely destroyed; half its population killed; all animals perished.

d) (SIL-23) $d$ number of houses damaged; an imamzadeh and a caravansarai were ruined; ganat water changed.

d) (KA(i-23) dll houses damaged.

DJD) (KAG-8) Totally destroyed; $4+$ people and all cattle killed; slumping of the ground; temporarily abandoned.

1) (Zunah, San, Zhan, ZHX-23) All houses damaged, a few collapsed, ground deformations.

D) (Zargina, KE(i-8) 10 out of 200 houses demolished killing much eattle; no casualties.

D) (Zarnu, JAP-23) Many houses ruined; old Armenian tower destroyed; ground deformations 


\section{ACKNOWLEDGFMENTS}

It is a pleasure to acknowlerge the assistance in this work of many colleagues and friends in Iran in the USSR and in the UK without whose aid such a study could not have been achieved. In particular, I would like to thank Mr. A. Moinfar and all members of his earthquake research team in the Plan and Burget Organisation, in Tehran, as well as in Kermanshah and Iamadan, who gave freely of their time in retrieving data and assisting in the field work. I would like to thank those who brought to my attention and provided me with a number of important documents, particularly the Soviet Seismological Commission Mr. C. Melville's help is greatly appreciated whatever success the writer has had in carrying out this piece of research was marle possible only by the generous assistance provided by many Iranians. This work was sponsored by the Natural Enviromment Research Council, Isondon.

\section{REFERENCES}

(11) Aybraskys N., Mommar A., 1973. - The Silakhor, Luristan earlhqualie of $23 \mathrm{rd}$ Jamury 1909. "Annali di Geof", XXVI, 4, pP. 659-678.

(12) Axonruous, 1909. - Zelsele-ye-Silakhor. Divan, Kermanshah.

(13) AsAD 'ALLAII MIRZA, 1909. - Manuseript mission report appended to letter no. 41 of Consul Nikolski, addressed to the Charge d'affairs of the Russian Mission at Tehran (dated 24th February o/s 1909), Kermanshal,, (unpublished).

(4) Bishor 1. I., 1891. - Journeys in Persia and Kurdistan. J. Murray, 2 vols., London.

(15) Bet. M. S., 1889. - A visit to the Karum River and Kum, "Blackwood's Marazine", 145. 882, pp. 453-481, Edinburgh.

(10) LaYard H., 1887. - Early advemhres in Persia, Susiana and Babylomia, J. Murray, 2 vols., Lomilon.

(17) Lowes W. K., 1856 . - Notes of a journey from Baghdad to Busrah with descriptions of several Chaldacan remains. "Journ. Roy. Googr. Soc.", 26.

(18) Meskosiax Y., 1954. - The Balhtiyaris, Basm.

(19) Morgas J. de 1895. - Mission seientifique en Perse. 2, "Lindes Geographiques", Paris.

(5i) Morgax J. de 1905. - Mission scientifique en Perse. 3, "Etudes Geologriques", P'aris. 
(51) Ninolski N., 1909a. - Letter report no. 38 of Russian Consul at Kermanshal to E. V. Sablin, Charge d Affairs at Imperial Mission Tehran (dated 18th February o/s, Komanshah (unpublished).

(52) Nikolski N., 1909b. - Letter report no. 41 of Russian Consul at Kermanshah to the Office of the Imperial Russian Mission to II. M. the Shah, Tehran (dated 24th February o/s) Kermanshah (unpublished).

$\left.{ }^{53}\right)$ Nikolski N., 1909c. - Ietter of Russian Consul at Kermanshah addressed to the First Department of the Ministry of Foreign Affairs at St. Petersburg (no. 42, dated 24th February o/s) Kermanshah (unpublished).

(54) Nikolski N., 19094. - Letter report of mission to Burujird earthquake area of Russian Consul at Kermanshah addressed to Nikolayev Central Observatory (dated February o/S). Kermanshah (unpublished).

(55) Nikolski N., 1909e. - Letter report of earthquake effects sent to Novoi Vremia, St. Petersburg (dated February o/s) Kermanshah (unpublished).

${ }^{(56)}$ SAWrER II. A., 1891. - Report of a reconnaissance in the Ballitiari country. "Publ. Govt. Central Printing House", Simla.

(57) SAwrer H. A., 1894. - The Bahhtiari mountains and Upper Elam "Geogr. Journ.", 4, 6, pp. 481-505. London.

$\left({ }^{58}\right)$ Sabiax E. V., 1909. - Appendix to report no. 167 of Russian Imperial Mission to II. M. the Shah at Tohran to the First Dept. Ministry of Foreign Affairs, St. Petersburg (no date). Tehran (unpublisher).

(59) Strauss 'Th., 1905. - Eime Reise an der Nordgrenze Luristans. "Peterm. Mitteil", 51, pp. 265-271, Gotha. 